\title{
No-take estuarine-protected areas: The missing armour for the conservation of fishes
}

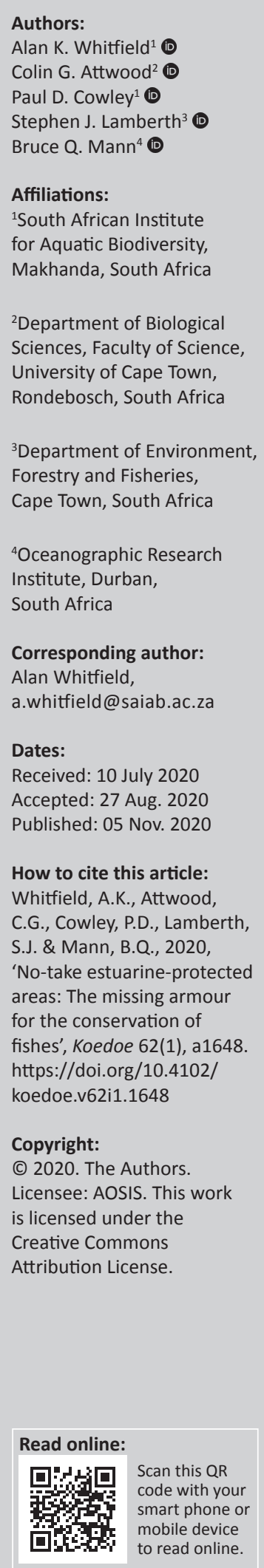

Stephen J. Lamberth ${ }^{3}$

Affiliations:

South African Institute

for Aquatic Biodiversity,

${ }^{2}$ Department of Biologica

Sciences, Faculty of Science

University of Cape Town,

${ }^{3}$ Department of Environment,

Forestry and Fisheries,

${ }^{4}$ Oceanographic Research

Institute, Durban

Alan Whitfield,

Dates:

Accepted: 27 Aug. 2020

S.J. \& Mann, B.Q, 2020,

'No-take estuarine-protected areas: The missing armour

for the conservation of

https://doi.org/10.4102/

is licensed under the

Creative Commons

Attribution License.
The focus of conservation attention over the past few decades has been on marine-protected areas (MPAs) providing protection for heavily exploited marine fish species. Although some estuaries are included in most large MPAs, specific attention on the protection needs of fish species in estuaries has been lacking. Furthermore, many of the estuaries located within conservation areas are open to angling activities and this has been exacerbated by the proliferation of illegal gillnet fishing in many systems during recent decades. Three fish species, the dusky kob Argyrosomus japonicus, white steenbras Lithognathus lithognathus and spotted grunter Pomadasys commersonnii - are used as examples of estuary-dependent taxa whose populations have been decimated by fishing over-exploitation, as well as habitat degradation caused by various human activities. By having complete protection for vulnerable fish species in certain estuaries, the potential benefits of increased catches for both subsistence and recreational anglers along the entire South African coastline could be substantial. If such protection is not offered to these species, then the downward spiral in fish catches will continue, to the ultimate detriment of both the people who currently use these protein resources for food security and those who are part of the economically important recreational fishing industry.

Conservation implications: Based on collapsing populations of targeted fishery species in estuaries, there is an urgent need to implement no-take estuarine-protected areas in each of the biogeographic regions along the South African coast.

Keywords: estuarine fishes; threatened species; protected areas; conservation; fisheries management; environmental management.

\section{Introduction}

South Africa was one of the few countries that took an early initiative in declaring marine-protected areas (MPAs) for biodiversity conservation (Attwood et al. 1997a; Attwood, Harris \& Williams 1997b). Support for these protected areas intensified when it became clear that they could assist in the recovery of depleted fishery resources (Attwood et al. 1997a; Buxton 1993). Although representation of biogeographic zones and habitats was recognised in 1995, the declaration of new MPAs at the end of that decade did not address the paucity of estuarine fish protection that was highlighted (Attwood et al. 1997b). Despite the fact that a number of marine fish species use estuaries as facultative or obligate nursery areas, there was little acknowledgement of this link in the proclamation of MPAs (Whitfield 1997), a situation that has not changed in the intervening decades (Whitfield \& Cowley 2010). More recent studies in South Africa have provided further conclusive evidence of the benefits of no-take MPAs to harvested fish stocks (Kerwath et al. 2013; Maggs, Mann \& Cowley 2013; Mann et al. 2016), including those found in estuarineprotected areas (Attwood et al. 2007; Da Silva et al. 2013; Hedger et al. 2010; Padare et al. 2020).

South African estuaries are home to 172 fish species (Whitfield 2019). Of these species, 37 (22\%) are marine 'stragglers' and make very limited use of estuaries. Marine fish species that use estuaries as nurseries and/or foraging areas comprise 73 (42\% of the total), but only $36(21 \%)$ of these are closely associated with estuaries (Whitfield 2019). Fish species that are resident and breed within estuaries comprise $25 \%$ (43 species) of all the taxa recorded in these systems. There is a high level of endemism, with 38 fish species (22\% of all estuary-associated taxa) occurring only in southern African waters (Whitfield 2019). 


\section{Why are estuaries important to fishes?}

The importance of connectivity between marine and estuarine ecosystems is globally recognised (e.g. Able 2005). In recent years, two diadromous fish species have gone extinct (Allibone et al. 2010; Freyhof \& Christian 2005), yet no fully marine fish species has gone extinct despite the latter being vastly more numerous and the target of industrial-scale fisheries speaks about the high risks confronted by estuarydependent fish. Our local piscine extinction candidates are either estuarine or freshwater. Two species of sawfish Pristis spp. have disappeared from South African estuaries (Everett et al. 2015), and the estuarine pipefish Syngnathus watermeyeri, once thought to be extinct (Whitfield \& Bruton 1996), is not far from that listing (Whitfield et al. 2017).

Estuaries are the conduits between marine and freshwater habitats - critical for the completion of life cycles of many fishes but threatened by land-based pollutants and growing numbers of catchment impoundments. Past MPAs did not factor in the important role of estuaries in the ecology of catadromous fish species, such as anguillid eels, whose glass eel larvae have to enter catchment rivers through estuaries (Bruton, Bok \& Davies 1987). Although the eels spend more than a decade of development in the freshwater environment (McEwan \& Hecht 1984), the ability of the adults to reach spawning grounds in the Indian Ocean (Tsukamoto, Aoyama \& Miller 2002) is dependent on safe passage through healthy and protected estuarine environments.

Estuaries are possibly the most threatened habitat realm in the country. There are 22 estuarine types represented in South Africa and $86 \%$ of these are threatened (Van Niekerk et al. 2019, 2020). About one-third of South Africa's freshwater is abstracted for agricultural, industrial and domestic use before it reaches the sea. This alone has reduced estuarine habitat, but what remains has been degraded further by habitat modification and pollution (Van Niekerk et al. 2019). The loss of fish nursery habitat, including saltmarsh, mangroves and intertidal foraging area, has effectively reduced a large number of fish populations by suppressing recruitment.

Over-exploitation poses the single biggest threat to estuarine fish conservation (Whitfield \& Cowley 2010; Table 1). Although more than 200 species are caught in South Africa's marine linefishery, very few species are targeted in estuarine fisheries, with the dominant species being the spotted grunter Pomadasys commersonnii, dusky kob Argyrosomus japonicus, leervis Lichia amia, white steenbras Lithognathus lithognathus and Cape stumpnose Rhabdosargus holubi (e.g. Baird, Marais \& Daniel 1996; Cowley et al. 2004). The number of species targeted in subtropical estuaries is slightly higher (James et al. 2001) than those in the more temperate systems. With the exception of Cape stumpnose, the stock status of all the highly targeted species is considered to be either overexploited or collapsed.
A pressing need for protecting estuaries resides with several iconic fish families that contain species targeted by recreational and subsistence fishers. The main use of estuaries by marine fish taxa in South Africa is as 0+ juveniles that usually spend between 1 and 3 years in these habitats (Wallace \& Van der Elst 1975). Species belonging to the families Mugilidae, Sparidae, Haemulidae, Sciaenid and Carangid are particularly well represented in estuaries on the subcontinent. Members of these families are economically important and well represented in estuarine and coastal fisheries. The juveniles of most of these species are largely restricted to estuaries but make occasional forays into the open sea (e.g. Bennett et al. 2017; Dames et al. 2017; Grant et al. 2017). Once they approach adulthood, these individuals return to the sea on a more permanent basis, where they are targeted with a variety of fishing methods (e.g. Childs et al. 2015; Murray et al. 2018). These fish contribute more than $90 \%$ of the catch of South Africa's shore-based and nearshore marine fisheries (Lamberth \& Tripe 2003).

\section{Current protection status for fishes in South African estuaries}

Over 3730 tonne of fish is caught annually in South Africa's estuaries, of which 2200 tonne $(60 \%)$ is by the illegal gillnet fishery (Van Niekerk et al. 2019). These estimates are conservative as the combined legal and illicit catch in St Lucia alone may be over 300 tonne to as much as 800 tonne per annum (Mann 1995; Turipe et al. 2014). Of over 500 gillnets confiscated from estuaries throughout South Africa that had some degree of protection in the form of conservator or fishery patrols, $60 \%$ were retrieved before having caught any fish. This implies that even current low levels of protection (and support for conservators) are helping to keep estuarine gillnet catch from surging past 4000 tonne per year. Increasing the number of estuarine-protected areas, accompanied by well-trained, motivated staff would most likely reduce gillnet catch to even lower levels.

The latest assessment of the coverage of estuarine-protected areas (EPAs), of which several types exist, shows that $48 \%$ of estuarine habitat is protected, but that the vast majority of this protection is either partial or ineffective (Box 1; Van

TABLE 1: Estimates of the relative importance of current major fish conservation issues in (1) freshwater, (2) estuarine and (3) marine ecosystems in South Africa.

\begin{tabular}{llll}
\hline Conservation issue & $\begin{array}{l}\text { Freshwater } \\
\text { ecosystem }\end{array}$ & $\begin{array}{l}\text { Estuarine } \\
\text { ecosystem }\end{array}$ & Marine ecosystem \\
\hline Habitat alteration & ++++ & +++ & + \\
Fish exploitation & ++ & ++++ & ++++ \\
Alien invasives & ++++ & ++ & + \\
Translocation & +++ & ++ & - \\
Genetic contamination & ++ & + & - \\
Parasite translocation & ++ & + & - \\
\hline
\end{tabular}

Source: Whitfield, A.K. \& Cowley, P.D., 2010, 'The status of fish conservation in South African estuaries', Journal of Fish Biology 76(9), 2067-2089. https://doi.org/10.1111/j.10958649.2010.02641.x.

Note: Habitat alteration includes physical changes to both estuary and catchment, water pollution and alterations in freshwater inputs.

- , not significant, + , insignificant, ++, slightly significant, +++, significant, ++++, highly significant. 
Niekerk et al. 2019). Turipe, Wilson and Van Niekerk (2012) modelled that 133 South African estuaries, including those already protected, would be required to meet defined biodiversity targets, including protection of fish. Of these, 61 should be fully protected no-take estuaries, whereas

BOX 1: Steps required for recovery of over-exploited fish species in South African estuaries.

- Creation of a network of estuarine-protected areas (EPAs) for fishes, which will include 'no-take' areas.

- Fisheries regulations rigorously enforced by dedicated staff, especially the removal of all illegal gill nets from estuaries.

- Commercial and small-scale fishing restricted to line-fishing and traditional fishing methods at acceptable effort levels.

- Environmental legislation fully implemented by the relevant authorities.

- Developing protocols for the prevention of pathogen transfer between estuaries by vessels and fishing gear.

- Implementation of the Environmental Water Reserve for estuaries by the Department of Water and Sanitation (DWS).

- Estuary Management Plans (EMPs) that include no-take zones are prioritised and implemented for all major estuaries.

- Improved fisher awareness and compliance with regulations, including greater adoption of catch and release fishing within all recreational sectors.

Source: Modified from Whitfield, A.K., Lamberth, S., Cowley, P. \& Mann, B., 2019 'Fisheries in South African estuaries - Are we on the right road?', The Water Wheel 18(6), 12-15.
72 require partial protection, including zoned no-take areas. This represents $46 \%$ of estuaries and $79 \%$ of estuarine area. Consequently, all EPAs should be explicit in the individual Estuary Management Plans required in terms of the Integrated Coastal Management Act (Act 24 of 2008).

Current estuarine ecosystem protection levels are low, both in terms of number of types and in area. Overall, 82\% (19 out of 22 types) of South Africa's estuarine ecosystem types are under-protected. Of estuarine area, less than $2 \%$ is well protected, $24 \%$ moderately protected, $63 \%$ poorly protected and 11\% not-protected (Van Niekerk et al. 2019). Seventytwo estuaries are in terrestrial protected areas and flow into MPAs, but few have any no-take status. Only $25(8 \%)$ of estuaries have no-take zones, representing less than $1 \%$ of total estuarine area. This is because of most of these being very small systems that fall entirely within an MPA (e.g. Klipdriftsfontein in De Hoop) but make a minimal contribution to total estuarine fish biomass or productivity (these very small systems are excluded from Figure 1).

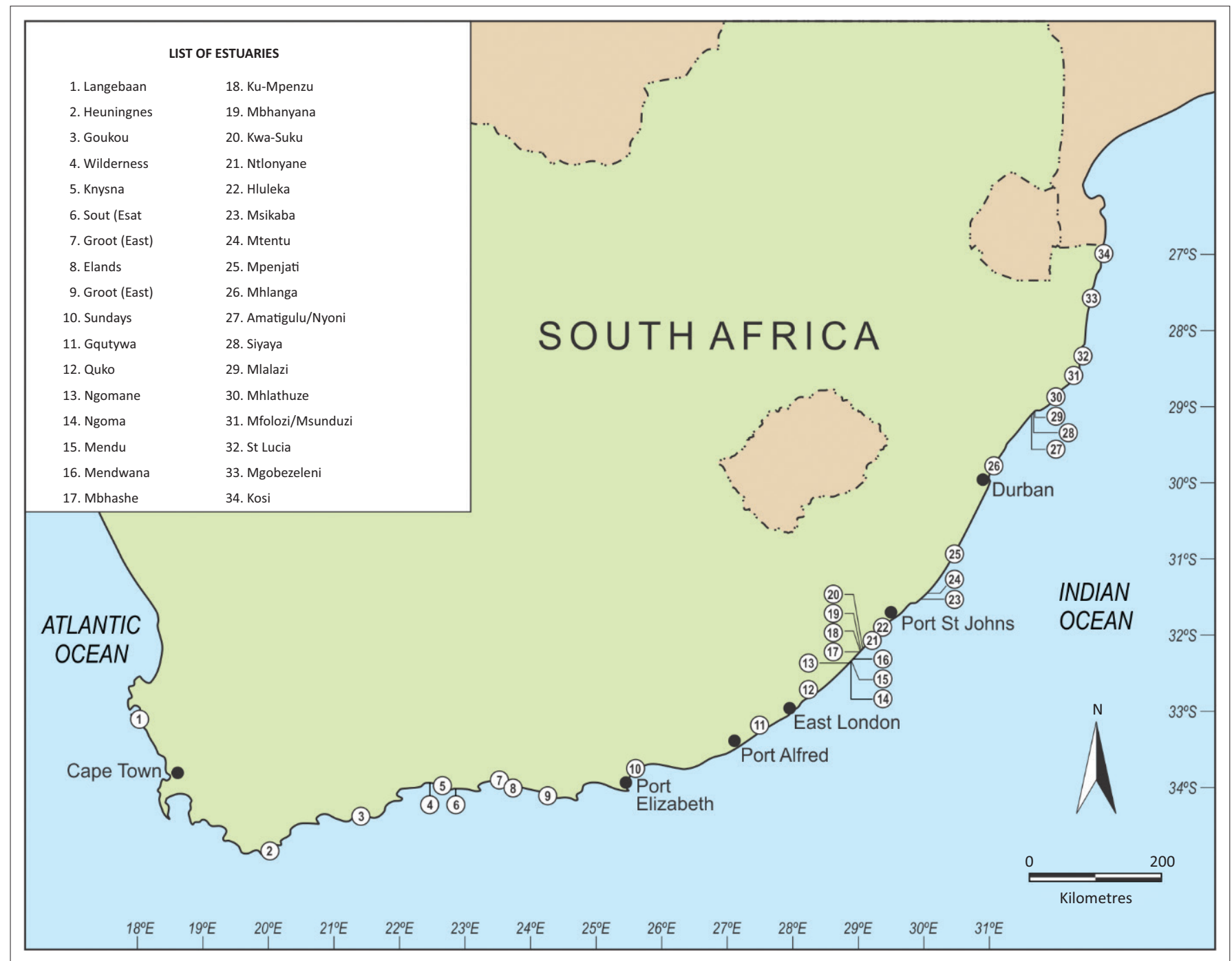

Source: Adapted from Whitfield, A.K., 2019, 'Fishes of Southern African estuaries: From species to systems', Smithiana Monograph No. 4, p. 495

FIGURE 1: Important South African functional estuaries (from a fish diversity and production perspective) that have a formally declared conservation status, even though fish stocks within these areas are often not protected from fishing activities. Very small protected estuaries and those larger systems that have only a minor portion of the water area conserved are not shown. 
The inclusion of estuaries within an MPA, or other types of protected areas, does not imply that fish are protected, as recreational and subsistence fishing in protected estuaries is usually permitted, for example, Mbhashe and Mbhanyana where angling effort is five times the national average. Many estuarine systems that have a national, provincial or municipal conservation status have management authorities that allow fishing, for example, Knysna and Goukamma. Langebaan is a Ramsar site and foundation of the West Coast National Park but supports a legal commercial gillnet fishery as well as commercial, small-scale and recreational line fishing. The combined catch exceeds 250 tonne per annum. Our concern is that the word 'protection' has been misapplied and that the two most common deficiencies in protected areas are the management of fishing and water quality (Van Niekerk et al. 2019).

Important estuaries (from a fish diversity and production perspective) currently situated in the footprint of conservation areas are concentrated in the eastern and south-eastern parts of the country (Figure 1). The largest and most important estuary in South Africa is the Lake St Lucia system, which covers almost $50 \%$ of the estuarine surface area in the country. Although forming a part of the World Heritage site and a Ramsar site of international importance, the fishes of the St Lucia system are not protected from fishing and illegal gill netting is common (Mann 1995, 2003). Furthermore, this system has been effectively closed to the sea since 2002, thus greatly reducing its nursery function for marine species (Vivier, Cyrus \& Jerling 2010). Also part of the iSimangaliso Wetland Park is the large Kosi Estuarine Lake system that, in addition to recreational angling, permits the extensive use of modified traditional Thonga fish traps and is simultaneously plagued by illegal gill netting (Kyle 2013). Clearly, the conservation status of fishes within these key estuarine systems needs to be reviewed and elevated.

\section{Fish species examples of why estuarine-protected areas are required}

Why are effective EPAs for fishes such an urgent requirement for the sustainability of fish stocks all along the South African coast? Just three examples should provide ample evidence to support EPA proclamations, not as addendums to MPAs, but as fully protected areas in their own right. The first species is the dusky kob A. japonicus, a member of the Sciaenidae family, which is the primary target of most recreational and subsistence fishers in the subtropical and warm temperate regions (Cowley, Childs \& Bennett 2013; Crook \& Mann 2002; Mann, James \& Beckley 2002; Potts et al. 2005). Dusky kob is now estimated to have a spawner stock biomass below 3\% of their pre-exploitation biomass (Winker et al. 2015). The South African dusky kob is now considered to be endemic to the subcontinent and is genetically distinct from $A$. japonicus in the rest of the Indo-Pacific region (Barnes et al. 2016). An additional threat is the reported hybridisation with the heavily depleted silver kob Argyrosomus inodorus (Mirimin et al. 2014).

The second example is the white steenbras L. lithognathus (Sparidae), which is targeted by fishers in warm- and coldtemperate regions. This large seabream had a spawner stock biomass < 6\% of pristine levels in 1990 (Bennett 1993) and ongoing monitoring has suggested further declines since then (Mann et al. 2014, http://dehoopfishmonitoring.uct. ac.za). The discovery of a handful of $0+$ juveniles in the Cunene Estuary on the Angola-Namibia border attests to what is left of a large historical West Coast spawning population depleted to near extinction by eight decades of intensive beach-seine netting straddling the late 19th and early 20th centuries. White steenbras bones and otoliths are a dominant fish component of archaeological middens on the West Coast (Poggenpoel 1996). By inference, it took just a few decades to nearly extirpate a population that had been in existence for more than 100000 years.

The third example relates to a tagging study by Padare et al. (2020) on spotted grunter P. commersonnii (330 mm - $650 \mathrm{~mm}$ fork length) in the Goukou Estuary (Western Cape). The results of this study further confirm the high site and estuarine fidelity by spotted grunter and the potential value of estuarine no-take area closures as a management option. The high site fidelity suggests that the closure of even a section of an estuary has the potential to reduce the vulnerability to capture of a portion of the locally resident population. The vulnerability of this species to fishing pressure within estuaries was highlighted by the loss of $43 \%$ of the tagged fish. Whilst this study revealed the potential benefit of no-take EPAs, the possible capture of several tagged fish within the no-take zone suggests that compliance is low and that law enforcement is inadequate at the Goukou Estuary.

\section{Some reasons why existing law enforcement measures are not working}

Whilst in theory improved management of the above iconic species could be achieved by catch restrictions, or even a total moratorium on catches of these species, law enforcement, and hence compliance with fishing regulations, is very poor across the country (Bova et al. 2017). A recent detailed study conducted on the Sundays Estuary revealed that more than $90 \%$ of the targeting effort was levelled at only two species, dusky kob and spotted grunter (Cowley et al. 2013). A large portion of the dusky kob catch comprised fish with lengths below the minimum legal size limit (i.e. $60 \mathrm{~cm}$ total length). The high retention rate of undersized fish is a major cause for concern. Sixty-three per cent of dusky kob and all white steenbras catches were below the legal size limit of $60 \mathrm{~cm}$, and $30 \%$ of spotted grunter were below the $40 \mathrm{~cm}$ size limit.

Size limits are a type of catch restriction that should become more effective as fishing pressure increases and reduces the average length of fish, but it still requires 
effective enforcement. The other commonly applied catch restriction, namely, bag limits, is more problematic. This type of restriction becomes less effective as fishing pressure increases (Attwood \& Bennett 1995), as the following evidence demonstrates. The daily bag limit (one fish per person per day) of legal-sized dusky kob in the Sundays Estuary was attained on only $2.6 \%$ of angler outings, whilst that for spotted grunter (five fish per person per day) was attained on only $0.1 \%$ of outings. No white steenbras larger than the legal size were captured (Cowley et al. 2013). The bag limits therefore have little practical value in these instances.

A detailed questionnaire survey revealed that most anglers were unaware of the fishing regulations pertaining to their targeted species and that only $71 \%$ of interviewees claimed to have a valid fishing permit (Cowley et al. 2013). The apparent lack of compliance can largely be ascribed to poor law enforcement. Most (59\%) of the respondents had never had their catch inspected, whilst $11 \%$ had encountered a law enforcement officer on only one previous outing. It is our opinion that EPAs (in which some or all of the estuary is protected from fishing) would offer far greater protection to estuarine fishery species, as long as their formal declaration includes dedicated management (conservation staff and budgets), as has been accorded to other protected areas.

Not surprisingly, both dusky kob and white steenbras are now listed as critically endangered on the International Union for Conservation of Nature Red List (Fennessy 2020; Mann et al. 2014). Similarly, many estuary-associated marine fish species are on the World Wildlife Fund Southern African Sustainable Seas Initiative Red List for the restaurant or retail trade as these may not be commercially sold or bought in South Africa. These include leervis, tenpounder, kingfish species, spotted grunter, two stumpnose species, estuarine bream and mangrove snapper.

\section{Conclusion}

The current political and economic environment makes it difficult to restrict fishing activities in any estuaries that are currently open to this activity. Indeed, the trend in recent years has been to open up parts of MPAs to fishing that were previously closed to angling (Lombard et al. 2020). However, by having complete protection for vulnerable and overexploited fish species in certain estuaries, the potential benefits of increased catches for both subsistence and recreational anglers along the entire South African coastline could be substantial. If such protection is not offered to these species, then the downward spiral in fish catches will continue, to the ultimate detriment of both the people who currently use these protein resources for food security and those who are part of the economically important recreational fishing industry. Indeed, the long-term survival of certain endemic species in estuaries on the subcontinent could well be threatened if these fish populations drop below critical levels, and the possibility then arises that recovery of the stocks becomes increasingly unlikely.

In conclusion, we recognise that the advantage of combining well-managed MPAs and EPAs is the complete protection of at least some vulnerable fish species in a particular area during all stages of their life cycle. Examples of this are the Stilbaai MPA and Greater Addo NP, which include no-take estuarine areas, and substantial parts of the adjacent coast. Protected areas of this type, and community-based conservancies or stewardship initiatives, will greatly assist in achieving the recovery of over-exploited estuarine fish stocks and support the survival of critically endangered species, such as the estuarine pipefish. However, we also see a need to protect catchment connectivity, estuarine habitat and vegetation, which are all vital for young catadromous fish stages and the return migration of adult eels to the sea. To accomplish this, it will be necessary to declare additional EPAs and to substantially improve the management of existing EPAs to ensure that we have adequate protection of our essential fish nursery habitats.

\section{Acknowledgements}

The authors thank their respective research organisations for financial, laboratory and logistical support to conduct fish research in South African estuaries.

\section{Competing interests}

The authors declare that they have no financial or personal relationships that may have inappropriately influenced them in writing this article.

\section{Authors' contributions}

This article was initiated by A.K.W. and all authors made contributions to the writing of the review.

\section{Ethical consideration}

This article followed all ethical standards for a research without direct contact with human or animal subjects.

\section{Funding information}

This research received no specific grant from any funding agency in the public, commercial or not-for-profit sectors.

\section{Data availability statement}

Data sharing is not applicable to this article as no new data were created or analysed in this study.

\section{Disclaimer}

The views and opinions expressed in this article are those of the authors and do not necessarily reflect the official policy or position of any affiliated agency of the authors.

\section{References}

Able, K.W., 2005, 'A re-examination of fish estuarine dependence: Evidence for connectivity between estuarine and ocean habitats', Estuarine and Coastal Shelf Science 64(1), 5-17. https://doi.org/10.1016/j.ecss.2005.02.002

Allibone, R., David, B., Hitchmough, R., Jellyman, D., Ling, N., Ravenscroft, P. \& Waters, J., 2010, 'Conservation status of New Zealand freshwater fish, 2009', 
New Zealand Journal of Marine and Freshwater Research 44(4), 271-287. https:// doi.org/10.1080/00288330.2010.514346

Attwood, C.G. \& Bennett, B.A., 1995, 'A procedure for setting daily bag limits on the recreational shore-fishery of the south-western Cape, South Africa', South African Journal of Marine Science 15(1), 241-252. https://doi.org/10.2989/0257761 95784156377

Attwood, C.G., Cowley, P.D., Kerwath, S.E., Naesje, T.F., Okland, F. \& Thorstad, E.B., 2007, First tracking of white stumpnose Rhabdosargus globiceps (Sparidae) in South African marine protected area', African Journal of Marine Science 29(1) 147-151. https://doi.org/10.2989/AJMS.2007.29.1.15.80

Attwood, C.G., Harris, J.M. \& Williams, A.J., 1997b, 'International experience of marine protected areas and their relevance to South Africa', South African Journo of Marine Science 18(1), 311-332. https://doi.org/10.2989/025776197784161162

Attwood, C.G., Mann, B.Q., Beaumont J. \& Harris, J.M., 1997a, 'Review of the state of marine protected areas in South Africa', South African Journal of Marine Science 18(1), 341-367. https://doi.org/10.2989/025776197784160910

Baird, D., Marais, J.F.K. \& Daniel, C., 1996, 'Exploitation and conservation of angling fish in two South African estuaries', Aquatic Conservation: Marine and Freshwater Ecosystems 6(4), 319-330. https://doi.org/10.1002/(SICI)1099-0755(199612) 6:4\%3C319::AID-AQC201\%3E3.0.CO;2-H

Barnes, T.C., Junge, C., Myers, S.A., Taylor, M.D., Rogers, P.J., Ferguson, G.J. et al., 2016 'Population structure in a wide-ranging coastal teleost (A. japonicus, Sciaenidae) reflects marine biogeography across southern Australia', Marine and Freshwater Research 67(8), 1103-1113. https://doi.org/10.1071/MF15044

Bennett, B.A., 1993, 'The fishery for white steenbras Lithognathus lithognathus off the Cape coast, South Africa, with some considerations for its management South African Journal of Marine Science 13(1), 1-14. https://doi.org/ $10.2989 / 025776193784287185$

Bennett, R.H., Cowley, P.D., Childs, A.-R., Attwood, C.G., Swart, L. \& Næsje, T.F., 2017 'Movement patterns of an endangered fishery species Lithognathus lithognathus (Sparidae) and the role of no-take marine protected areas as a management tool African Journal of Marine Science 39(4), 475-489. https://doi.org/10.2989/18142 32X.2017.1404493

Bova, C.S., Halse, S.J., Aswani, S. \& Potts, W.M., 2017, 'Assessing a social norms approach for improving recreational fisheries compliance', Fisheries Management and Ecology 24(2), 117-125. https://doi.org/10.1111/fme.12218

Buxton, C.D., 1993, 'Life-history changes in exploited reef fishes on the east coast of South Africa', Environmental Biology of Fishes 36(1), 47-63. https://doi. org/10.1007/BF00005979

Bruton, M.N., Bok, A.H. \& Davies, M.T.T., 1987, 'Life history styles of diadromous fishes in inland waters of Southern Africa', American Fisheries Society Symposium 1, 104-121.

Childs, A.-R., Cowley, P.D., Næsje, T.F. \& Bennett, R.H., 2015, 'Habitat connectivity and intra-population structure of an estuary-dependent fishery species', Marine Ecology Progress Series 537, 233-245. https://doi.org/10.3354/meps11456

Cowley, P.D., Childs, A.-R. \& Bennett, R.H., 2013, 'The trouble with estuarine fisheries in temperate South Africa, illustrated by a case study on the Sundays Estuary', African Journal of Marine Science 35(1), 117-128. https://doi.org/10.2989/18142 32X.2013.789079

Cowley, P.D., Wood, A.D., Corroyer, B., Nsubuya, Y. \& Chalmers, R., 2004, 'A survey of fishery resource utilization on four Eastern Cape estuaries (Great Fish, West fishery resource utilization on four Eastern Cape estuaries (Great Fish, West
Kleinemond, East Kleinemond and Kowie)', in Protocols Contributing to the Management of Estuaries in South Africa, with a Particular Emphasis on the Eastern Cape Province, vol. III, Project C, Supplementary Report C5, pp. 129-165, Water Research Commission, Pretoria.

Crook, B.J.S. \& Mann, B.Q., 2002, 'A critique of and recommendations for a subsistence fishery, Lake St Lucia, South Africa', Biodiversity and Conservation 11(7), 1223-1235. https://doi.org/10.1023/A:1016074802295

Dames, M.H., Cowley, P.D., Childs, A.-R., Bennett, R.H., Thorstad, E.B. \& Næsje, T.F, 2017, 'Estuarine and coastal connectivity of an estuarine-dependent fishery species, Pomadasys commersonnii (Haemulidae)', African Journal of Marine Science 39(1), 111-120. https://doi.org/10.2989/1814232X.2017.1305991

Da Silva, C., Kerwath, S.E., Attwood, C.G., Thorstad, E.B., Cowley, P.D., Okland, F., Wilke, C.G. \& Naesje, T.F., 2013, 'Quantifying the degree of protection afforded by a no-take marine reserve on an exploited shark', African Journal of Marine Science 35(1), 57-66. https://doi.org/10.2989/1814232X.2013.769911

Everett, B.I., Cliff, G., Dudley, S.F.J., Wintner, S.P. \& Van der Elst, R.P., 2015, 'Do sawfish Pristis spp. represent South Africa's first local extirpation of marine elasmobranchs in the modern era?', African Journal of Marine Science 37(2), 275-284. https:// doi.org/10.2989/1814232X.2015.1027269

Fennessy, S., 2020, Argyrosomus japonicas, 'The IUCN Red List of Threatened Species 2020', e.T49145403A49234015. https://doi.org/10.2305/IUCN.UK.2020-1. RLTS.T49145403A49234015.en

Freyhof, J. \& Christian, S., 2005, 'The houting Coregonus oxyrinchus (L.) (Salmoniformes: Coregonidae), a globally extinct species from the North Sea basin', Journal of Fish Biology 67(3), 713-729. https://doi.org/10.1111/j.0022 1112.2005.00771.x

Grant, G.N. Cowley, P.D., Bennett, R.H., Murray, T.S. \& Whitfield, A.K., 2017, 'Space use by Rhabdosargus holubi in a southern African estuary, with emphasis on fish movements and ecosystem connectivity', African Journal of Marine Science 39(2), 135-143. https://doi.org/10.2989/1814232X.2017.1327887

Hedger, R.D., Naesje, T.F., Cowley, P.D., Thorstad, E.B., Attwood, C.G., Okland, F. et al. 2010, 'Residency and migratory behaviour by adult Pomatomus saltatrix in South African coastal embayment', Estuarine, Coastal and Shelf Science 89(1), 12-20. https://doi.org/10.1016/j.ecss.2010.04.013
James, N.C., Beckley, L.E., Mann, B.Q. \& Kyle, R., 2001, 'The recreational fishery in the Kosi estuarine lake system, South Africa', African Zoology 36(2), 217-228. https:// doi.org/10.1080/15627020.2001.11657140

Kerwath, S.E., Winker, H., Gotz, A. \& Attwood, C.G., 2013, 'Marine protected area improves yield without disadvantaging fishers', Nature Communications 4(2347), 1-6. https://doi.org/10.1038/ncomms3347

Kyle, R., 2013, 'Thirty years of monitoring traditional fish trap catches at Kosi Bay, KwaZulu-Natal, South Africa, and management implications', African Journal of Marine Science 35(1), 67-78. https://doi.org/10.2989/181423 2X.2013.769905

Lamberth, S.J. \& Turpie, J.K., 2003, 'The role of estuaries in South African fisheries: Economic importance and management implications', South African Journal of Marine Science 25(1), 131-157. https://doi.org/10.2989/18142320309504005

Lombard, A.T., Durbach, I., Harris, J.M., Mann-Lang, J.B., Mann, B.Q., Branch, G.M et al., 2020, 'South Africa's Tsitsikamma Marine Protected Area - Winners and losers', in J. Humphreys \& R.W.E. Clark (eds.), Marine protected areas: Science, policy and management, pp. 237-260, Elsevier, Amsterdam.

Maggs, J.Q., Mann, B.Q. \& Cowley, P.D., 2013, 'Contribution of a large no-take zone to the management of vulnerable reef fishes in the south-west Indian Ocean', Fisheries Research 144, 38-47. https://doi.org/10.1016/j.fishres.2012. 10.003

Mann, B.Q., 1995, 'Quantification of illicit fish harvesting in the Lake St Lucia Game Reserve, South Africa', Biological Conservation 74(2), 107-113. https://doi. org/10.1016/0006-3207(95)00019-Z

Mann, B.Q., 2003, 'The St Lucia subsistence gillnet fishery', in M. Hauck \& M. Sowman (eds.), Waves of change: Coastal and fisheries co-management in Southern Africa, pp. 99-122. UCT Press, Cape Town.

Mann, B.Q., Buxton, C.D., Pollard, D., Carpenter, K.E. \& Iwatsuki, Y., 2014, 'Lithognathus lithognathus. The IUCN Red List of Threatened Species 2014', e.T12137A505458. https://doi.org/10.2305/IUCN.UK.2014-3.RLTS.T12137A505458.en

Mann, B.Q., James, N.C. \& Beckley, L.E., 2002, 'An assessment of the recreational fishery in the St Lucia estuarine system, KwaZulu-Natal, South Africa', South African Journal of Marine Science 24(1), 263-279. https://doi.org/10.2989/ 025776102784528330

Mann, B.Q., Winker, H., Maggs, J.Q. \& Porter, S., 2016, 'Monitoring the recovery of a previously exploited surf-zone fish community in the St Lucia Marine Reserve using a no-take sanctuary area as a benchmark', African Journal of Marine Science 38(3), 423-441. https://doi.org/10.2989/1814232X.2016.1224779

McEwan, A. \& Hecht, T., 1984, 'Age and growth of the longfin eel Anguilla mossambica Peters, 1852 (Pisces, Anguillidae) in Transkei rivers', African Zoology 19(4), 280-285. https://doi.org/10.1080/02541858.1984.11447894

Mirimin, L., Kerwath, S.E., Macey, B.M., Bester-van der Merwe, A.E., Lamberth, S.J., Bloomer, P. et al., 2014, 'Identification of naturally occurring hybrids between two overexploited sciaenid species along the South African coast', Molecular Phylogenetics and Evolution 76, 30-33. https://doi.org/10.1016/j.ympev.2014.02.010

Murray, T., Cowley, P., Bennett, R. \& Childs A.-R., 2018, 'Fish on the move: Connectivity of an estuary-dependent fishery species evaluated using a large-scale acoustic telemetry array', Canadian Journal of Fisheries and Aquatic Sciences 75(11) 2038-2052. https://doi.org/10.1139/cjfas-2017-0361

Padare, G., Cowley, P.D., Vumazonke, L.U., Murray, T.S., du Plessis, J. \& Lamberth, S.J., 2020 . 'Can partial estuarine area protection reduce the vulnerability to capture of
spotted grunter Pomadasys commersonnii?', in T.S. Murray, M.I. Duncan, A.C. Winkler, A.-R Childs, B.Q. Mann \& W.M. Potts (eds.), Linefish Resilience in the Anthropocene: The Proceedings of the 5th Southern African Marine Linefish Symposium, , 113 pp., Rhodes University, Makhanda.

Poggenpoel, C.A., 1996. 'The exploitation of fish during the Holocene in the southwestern Cape, South Africa', MA thesis, University of Cape Town, Rondebosch.

Potts, W.M., Cowley, P.D., Corroyer, B. \& Næsje, T.F., 2005, 'Trends in fishery resource utilisation on the Great Fish Estuary', NINA Report 50, 34.

Turpie, J.K., Feigenbaum, T., Hayman, M., Hutchings, K., Cousins, T., Chipeya, T. et al., 2014, 'Analysis of alternatives to determine the most feasible solution to the hydrological issues of the Lake St Lucia estuarine system, Volume IV: Socioeconomic assessment', Report prepared by Anchor Environmental Consultants for economic assessment', Report prepared by Anchor En
iSimangaliso Wetland Park Authority, KwaZulu-Natal.

Turpie, J.K., Wilson, G. \& Van Niekerk, L., 2012, 'National biodiversity assessment 2011: National estuary biodiversity plan for South Africa', Anchor Environmental Consultants Report No AEC2012/01, Report produced for the Council for Scientific and Industrial Research and the South African National Biodiversity Institute, and Industrial
Cape Town

sukamoto, K., Aoyama, J. \& Miller, M.J, 2002, 'Migration, speciation, and the evolution of diadromy in anguillid eels', Canadian Journal of Fisheries and Aquatic evolution of diadromy in anguillid eels', Canadian Journal of Fish
Science 59(12), 1989-1998. https://doi.org/10.1139/f02-165

Van Niekerk, L., Adams, J.B., James, N.C., Lamberth, S.J., Mackay, C.F., Turpie, J.K. et al., 2020, 'An Estuary Ecosystem Classification that encompasses biogeography, estuary size and types in support of estuarine protection, conservation and estuary size and types in support of estuarine protection, conservation and
management', African Journal of Aquatic Science 45(1-2), 199-216. https://doi. management', African Journal of Aqua
org/10.2989/16085914.2019.1685934

Van Niekerk, L., Adams, J.B., Lamberth, S.J., MacKay, C.F, Taljaard, S., Turpie, J.K. et al (eds.), 2019, 'South African national biodiversity assessment 2018: Technical (eds.), 2019, 'South African national biodiversity assessment 2018: Technical
report. Volume 3: Estuarine realm', Report No. SANBI/NAT/NBA2018/2019/ Vol3/A, South African National Biodiversity Institute, Pretoria.

Vivier, L., Cyrus, D.P. \& Jerling, H.L., 2010, 'Fish community structure of the St Lucia estuarine system under prolonged drought conditions and its potential for
recovery after mouth breaching', Estuarine, Coastal and Shelf Science 86, recovery after mouth breaching, Estuarine, Coastal
568-579. https://doi.org/10.1016/j.ecss.2009.11.012 
Wallace, J.H. \& Van der Elst, R.P., 1975, 'The estuarine fishes of the east coast of South Africa. Part 4. Occurrence of juveniles in estuaries. Part 5. Ecology, estuarine dependence and status', Investigational Report of the Oceanographic Research Institute 42, 1-63.

Whitfield, A.K., 1997, 'Fish conservation in South African estuaries', Aquatic Conservation: Marine and Freshwater Ecosystems 7(1), 1-11. https://doi. org/10.1002/(SICI)1099-0755(199703)7:1\%3C1::AID-AQC213\%3E3.0.CO;2-8

Whitfield, A.K., 2019, 'Fishes of Southern African estuaries: From species to systems', Smithiana Monograph No. 4, p. 495.

Whitfield, A.K. \& Bruton, M.N., 1996, 'Extinction of the river pipefish Syngnathus watermeyeri in the Eastern Cape Province, South Africa', South African Journal of Science $92(2), 59-60$.
Whitfield, A.K. \& Cowley, P.D., 2010, 'The status of fish conservation in South African estuaries', Journal of Fish Biology 76(9), 2067-2089. https://doi.org/10.1111/ j.1095-8649.2010.02641.x

Whitfield, A.K., Lamberth, S., Cowley, P. \& Mann, B., 2019, 'Fisheries in South African estuaries - Are we on the right road?', The Water Wheel 18(6), 12-15.

Whitfield, A.K., Mkare T., Teske, P.R., James, N.C. \& Cowley, P.D., 2017, 'Life-histories explain the conservation status of two estuary-associated pipefishes', Biological Conservation 212, 256-264. https://doi.org/10.1016/j.biocon.2017.06.024

Winker, H., Attwood, C. \& Kerwath, S., 2015. 'Assessment of stock abundance of inshore fish resources included in the "basket-of-species" to be allocated under the small-scale fisheries policy', Unpublished Report, Department of Agriculture, Forestry and Fisheries, LSWG Feb 2015-1, p. 69. 